\title{
DOING NEW THINGS WITH LANGUAGE: NARRATIVE LANGUAGE IN SLI PRESCHOOLERS
}

\author{
Ingrida Balčiūnienè, Aleksandr N. Kornev
}

\begin{abstract}
The paper deals with micro- and macrostructural static and dynamic narrative characteristics in specifically language-impaired (SLI) Russian-speaking preschool children and their typically-developing (TD) peers. The study was based on experimental data that included storytelling and retelling elicited by means of wordless picture sequences. First, individual measures of story structure, episode completeness, internal state terms, story productivity, lexical diversity, and syntactic complexity, as well as the percentage of linguistic dysfluencies and errors, were evaluated and compared between the experimental and control groups. Second, the impact of such factors as session (1st vs. 2nd), story complexity, and mode (telling vs. retelling) on the dynamic variation of micro- and macrostructural narrative measures was evaluated. Our results highlighted essential dynamic differences between the samples from the perspective of narrative structure, structural complexity, grammaticality, and vocabulary.*
\end{abstract}

Keywords: narrative analysis, discourse analysis, dynamic variation, language impairment, language assessment, Russian

\section{Introduction}

Learning language structures considered the main challenge for specifically language-impaired (SLI) children, thus morphosyntactic and lexical limitation, is still the main target in SLI studies (van der Lely 1997, Leonard 2014). The most serious disadvantages in the SLI population are related to discourse processing in daily life communication. However, relatively few studies have dealt with discourse production/comprehension.

Among the different genres of discourse, narrative is culturally the most essential but also the most demanding. A number of studies have evidenced that 5-6 year-old typically-developing (TD) children are already capable of generating so called 'true narrative' (Applebee 1978, Gillam, Pearson 2004). Both personal and

* The research was supported by the Russian Foundation for Humanities, grant No. 14-04-00509 Formirovanie 
fictional narratives have a huge conversational value (Nelson 1996). On the other hand, narrative macro- and microstructure depend on the context and situation of the conversation, i.e. for whom, what for and where the storytelling occurs (McCabe, Bliss 2003). Narrative generation is a complex process incorporating both linguistic and cognitive operations such as planning, speech processing, logical reasoning, and developing coherent and cohesive structures (Hickmann, Hendriks 1999). These two lines of storytelling, i.e. linguistic and cognitive processing, are in concurrent relations (Colozzo et al. 2011). Consequently, narrative measures are very dependent on multiple internal (personal) and external (circumstantial) conditions of the conversation (e.g. child-child talk vs. child-adult conversation). Thus we need an appropriate sensitive tool that would allow for evaluation of all of these variables. During the past decades, various instruments for narrative assessment have been developed: e.g., different versions of The Frog Story (Mayer 1967, 1969, 1974, etc.), The Bus Story (Renfrew 1969), The Cat Story and The Horse Story (Hickmann 2003), The Stone Story (Veneziano, Hudelot 2009), TNL (Gillam, Pearson 2004), ENNI (Schneider et al. 2005), INMIS (Justice et al. 2006), MAIN (Gagarina et al. 2012, 2015). Certainly, assessment conditions, task mode (telling/retelling), and picture sequence complexity (1-23 pictures) vary widely across these instruments. And, finally, a number of various parameters and their combinations should be analyzed in order to evaluate general narration skills. For example, following Justice et al. (2006), microstructural (linguistic) analysis should include nine measures, i.e. three indices for story productivity and six indices for structural complexity. Story productivity is measured by the total number of words, total number of different words, and total number of terminal units. Structural complexity is represented by the mean length of terminal units (in words and morphemes), total number of terminal units that contained two or more clauses, total number of coordinating and subordinating conjunctions, and the proportion of complex terminal units. Macrostructural analysis might be based on different measures, depending on the particular methodological approach. E.g., following Applebee (1978), fictional stories and some personal narratives can be classified into six types (levels): heaps, sequences, primitive narratives, unfocused chains, focused chains, and true narratives. Later on, this classification was extended (Larson, McKinley 1995) by adding four types (i.e. narrative summaries, complex narratives, analysis, and generalizations) that characterize higher-level narratives and thus may be used when analyzing stories told by school-age children. Another approach to a narrative macrostructure is to examine it for the presence of story grammar parts (also called 'episodes') and to assign it to a story structure level (Hughes et al. 1997). A history and variability of Story Grammar analysis should be noted here. During the past decades, several variations of story grammar have been developed, but Stein and Glenn's approach $(1979,1982)$ seems to be applied most commonly. Following this model, a good story should contain four obligatory episodes, i.e. an initiating event (or problem), attempt, consequence, and resolution (or reaction), and might contain additional optional episodes, such as setting, internal response, internal plan, and ending (Hughes et al. 1997). It should be noted however that the episodic analysis is considered to be relevant mainly for fictional stories. Macrostructural analysis of personal narratives should be based on other measures, such as topic maintenance, event sequencing, explicitness, referencing, conjunctive cohesion, and fluency (Bliss et al. 1998). 
In the most comprehensive studies, both micro- and macrostructure of narrative texts have been analyzed (Fey et al. 2004, Reilly et al. 2004, Colozzo et al. 2011, van Kleeck et al. 2011, Vandewalle et al. 2012); however, the results of the studies seem to be controversial. It should be particularly emphasized that the vast majority of narrative studies have dealt with text as a 'product' of narration and only few of them have tended to evaluate the dynamic individual variations in the storytelling process and in narrative macro-/microstructure (Miller et al. 2001, Kramer et al. 2009). Thus we still need complex process-oriented studies in narrative analysis.

As it might be expected, narrative microstructure in language disordered children is usually less developed than in their TD peers. Some data have evidenced that SLI children are less productive in communication units (Colozzo et al. 2011, Reuterskiöld et al. 2011), morphemes, and words (Wetherell et al. 2007) than their TD peers. SLI children use fewer different words per story (Fey et al. 2004, Wetherell et al. 2007), as well as fewer mental and linguistic verbs, adverbs, and elaborated nouns (Squires et al. 2014). Grammatical measures such as the mean length of utterance (Vandewalle et al. 2012), the mean length of communication unit (Colozzo et al. 2011), syntactic diversity (Reilly et al. 2004), clausal density (Fey et al. 2004, Colozzo et al. 2011), the percentage of grammatical utterances (Fey et al. 2004, Colozzo et al. 2011, Reuterskiöld et al. 2011, Duinmeijer et al. 2012), the percentage of sentences containing two finite verbs (Duinmeijer et al. 2012), the proportion of complex syntax (Reilly et al. 2004), the proportion of different verbs per communication unit (Reuterskiöld et al. 2011), the total number of syntactic units (Wetherell et al. 2007), and coordinating and subordinating conjunctions (Squires et al. 2014) are also less developed in SLI children than in their TD peers. Some measures of narrative macrostructure have also been found to be impaired in the SLI population. According to Bliss et al. 1998, topic maintenance, event sequencing, explicitness, referencing, conjunctive cohesion, and fluency are less elaborated in the SLI population than in the TD one. The number of story elements (Colozzo et al. 2011, Reuterskiöld et al. 2011, Squires et al. 2014) and number of propositions (Reilly et al. 2004) are lower, while the percentage of non-communicative words (Duinmeijer et al. 2012) is higher in the SLI children than in their TD peers. Additionally, the SLI narratives are not as informative as those told by TD children (Vandewalle et al. 2012); finally, the SLI children, when telling a story, need more prompts and other support from the experimenter (Wetherell et al. 2007).

Besides empirical studies, a number of papers have dealt with methodological issues, e.g. Fiestas and Peña (2004) have analyzed the effect of different stimuli on narrative macrostructure in monolingual and bilingual children; Schneider (1996), Schneider and Dubé (2005) have compared the effect of oral, pictorial, and combined presentation of stimuli on story retell content; Bokus and Wales-Shugar (1998) have studied the impact of shared vs. non-shared access to topical sources of narration, the age and status of the listener, and the listener's task on storytelling. Soodla et al. (2010) have compared the effect of different story modes (telling and retelling) in TD and SLI children; Peña et al. (2006) have evaluated the impact of mediated teaching on TD and SLI children's narrative; Caramelli et al. (1998) have analyzed the way children's conceptual organization shapes their narrative performance. In this respect, narrative development studies in the typical and clinical population need a wider and more complex approach from the psycholinguistic 
and conversational perspective. Narrative production studies in the SLI population should take into account both linguistic and cognitive processes.

In this study, we recognize three objectives: 1) to apply the new complex narrative analysis tool RAIN (Russian Assessment Instrument for Narratives), which provides new possibilities to evaluate narrative from the linguistic, conversational, and cognitive perspective; 2) to evaluate micro- and macrostructural characteristics of SLI children in story (re-)telling; 3) to estimate the influence of some variables on narrative text measures. The latter includes analysis of non-linguistic variables (such as visual stimuli complexity, story mode, and session) and its impact on the narrative generation procedure in both TD and SLI children. The study is innovative from the perspective of the conversational and procedural dynamic methodological approach; it also might be treated as one of the first attempts to compare narrative production under different conditions including telling vs. retelling mode, task order, and general complexity of the visual stimuli.

\section{Design of the experiment}

\subsection{Participants}

The subjects of the present study were 12 clinically-referred monolingual Russianspeaking 6-year-old SLI children (mean age 76 months) and 12 typically developing peers (mean age 76 months). The SLI children were recruited from those who attended remedial treatment units for speech and language disordered kindergarteners. All of them have received a one-year treatment course (five lessons per week). The inclusion criteria were backwardness in morphosyntactic development (below age 5 level) coupled with articulation/phonological disorders. Children with a nonverbal IQ of below 84 percent on Raven's matrix were excluded. TD children were recruited from a daycare center for kindergartens. For both the samples, informed consent was obtained from parents before the experiment.

\subsection{Stimuli}

For the study, the Multilingual Assessment Instrument for Narratives - MAIN (Gagarina et al. 2012), as a narrative elicitation scheme, was modified and extended by the authors of the current paper. The new instrument, named the Russian Assessment Instrument for Narratives (RAIN), allows for evaluating both the current state of narrative language and the level of potential development under adult guidance ("zone of proximal development").

Hence, two picture sequences The Baby Birds and The Baby Goats, were applied for a narrative elicitation. Each sequence consists of six colored pictures $(10 \times 10 \mathrm{~cm}$ ), without a text. Originally, the authors of the visual stimuli (Gagarina et al. 2012) have aimed for congruence between the scripts and between the pictorial content by creating parallel storylines for the picture sequences (see Table 1). 
Table 1. Pictorial content and macrostructural framework of the stimuli

\begin{tabular}{|c|c|c|c|}
\hline \multirow[t]{2}{*}{ Episode } & $\begin{array}{l}\text { Structural } \\
\text { element }\end{array}$ & Baby Birds & Baby Goats \\
\hline & Setting & One day... & Once upon a time... \\
\hline \multirow{5}{*}{1} & Internal state term & Baby birds are hungry. & Baby goat is scared. \\
\hline & Goal & $\begin{array}{l}\text { The mother bird wants to feed } \\
\text { her chicks. }\end{array}$ & $\begin{array}{l}\text { The mother goat wants to help } \\
\text { her baby goat. }\end{array}$ \\
\hline & Attempt & The mother bird flies away. & The goat runs into the water. \\
\hline & Outcome & $\begin{array}{l}\text { The mother bird comes back } \\
\text { with a warm. }\end{array}$ & $\begin{array}{l}\text { The goat pushes her baby out of } \\
\text { the water. }\end{array}$ \\
\hline & Internal state term & A cat is hungry. & A fox is hungry. \\
\hline \multirow{5}{*}{2} & Internal state term & $\begin{array}{l}\text { The cat wants to catch the } \\
\text { chicks. }\end{array}$ & $\begin{array}{l}\text { The fox wants to catch the other } \\
\text { baby goat. }\end{array}$ \\
\hline & Goal & $\begin{array}{l}\text { The cat wants to catch the } \\
\text { chicks. }\end{array}$ & $\begin{array}{l}\text { The fox wants to catch the other } \\
\text { baby goat. }\end{array}$ \\
\hline & Attempt & The cat starts climbing the tree. & The fox grabs the baby goat. \\
\hline & Outcome & The dog stops the cat. & A bird stops the fox. \\
\hline & Internal state term & $\begin{array}{l}\text { The cat is still hungry and } \\
\text { scared by the dog. }\end{array}$ & $\begin{array}{l}\text { The fox is still hungry and scared } \\
\text { by the bird. }\end{array}$ \\
\hline \multirow{5}{*}{3} & Internal state term & $\begin{array}{l}\text { The dog sees the cat climbing } \\
\text { the tree. }\end{array}$ & $\begin{array}{l}\text { The bird sees the fox grabbing } \\
\text { the baby goat. }\end{array}$ \\
\hline & Goal & $\begin{array}{l}\text { The dog wants to help the } \\
\text { chicks. }\end{array}$ & $\begin{array}{l}\text { The bird wants to help the baby } \\
\text { goat. }\end{array}$ \\
\hline & Attempt & The dog grabs the cat's tail. & The bird grabs the fox's tail. \\
\hline & Outcome & The cat runs away. & The fox runs away. \\
\hline & Internal state term & $\begin{array}{l}\text { The dog is happy to help the } \\
\text { chicks. }\end{array}$ & $\begin{array}{l}\text { The bird is happy to help the } \\
\text { baby goat. }\end{array}$ \\
\hline
\end{tabular}

However, The Baby Goats sequence seems to be more complex to perceive because of slightly overlapping episodes and less familiar protagonists, thus can be treated as relatively more difficult for children. Some evidence for this distinction was obtained in our previous studies (Kornev, Balčiūnienẻ 2014, 2015).

\subsection{Procedure of narrative elicitation and analysis}

After warm-up, the subjects from both the experimental and the control groups performed two tasks, i.e. story generation (so-called storytelling) and story retelling (see Table 2); both of the tasks were followed by ten comprehension questions that focused on macrostructural components and internal state terms. Each child was tested individually; sessions of the 1st and the 2nd task were separated by a few minutes of free talk between the interviewer and the child. The order of tasks was counterbalanced with regard to story complexity and narrative mode (see Table 2). 
Table 2. Counterbalancing scheme

\begin{tabular}{|l|l|l|}
\hline Child No. & Session No. $\mathbf{1}$ & Session No. $\mathbf{2}$ \\
\hline $1,5,9$ & Telling Baby Birds & Retelling Baby Goats \\
\hline $2,6,10$ & Telling Baby Goats & Retelling Baby Birds \\
\hline $3,7,11$ & Retelling Baby Birds & Telling Baby Goats \\
\hline $4,8,12$ & Retelling Baby Goats & Telling Baby Birds \\
\hline
\end{tabular}

All the stories were video-recorded and transcribed according to $\mathrm{CHAT}^{1}$ (MacWhinney 2010) tools. Then, all the transcripts were morphologically encoded using The program of morphological coding $\left(\mathrm{MORCOMM}^{2}\right)$ (Gagarina et al. 2003). In addition to the morphological encoding, discourse encoding of the transcripts was completed.

\subsection{Measures}

During the analysis, the main individual macro- and microstructural indicators as well as linguistic errors and dysfluencies were evaluated and compared both within and between the groups.

\subsubsection{Macrostructural characteristics}

Story structure. Each structural component, i.e. setting, goal, attempt, and outcome (see Table 3), was given 1 point; thus the story structure scores range from $0-10$ points in total.

Episode completeness. Each complete episode (i.e. Goal-Attempt-Outcome sequence) was given 4 points (see Table 3 ).

Table 3. Scoring episode completeness

\begin{tabular}{|l|l|l|c|}
\hline Episode & \multicolumn{1}{|c|}{ Structure } & \multicolumn{1}{|c|}{ Example of an episode } & Points \\
\hline \multirow{5}{*}{ Complete } & $\begin{array}{l}\text { Goal-Attempt- } \\
\text { Outcome }\end{array}$ & $\begin{array}{l}\text { The mother-bird wanted to feed her chicks. She flied } \\
\text { away and brought them a warm. }\end{array}$ & 4 \\
\hline \multirow{5}{*}{ Incomplete } & Goal-Outcome & $\begin{array}{l}\text { The mother-bird wanted to feed her chicks and bring } \\
\text { them a warm. }\end{array}$ & 3 \\
\cline { 2 - 4 } & Goal-Attempt & $\begin{array}{l}\text { The mother-bird wanted to feed her chicks, thus she flied } \\
\text { away. }\end{array}$ & 2 \\
\cline { 2 - 4 } & $\begin{array}{l}\text { Attempt- } \\
\text { Outcome }\end{array}$ & $\begin{array}{l}\text { The mother-bird flied away and brought a warm to her } \\
\text { chicks. }\end{array}$ & 2 \\
\cline { 2 - 4 } & Bare Goal & The mother-bird wanted to feed her chicks. & 1 \\
\hline
\end{tabular}

\footnotetext{
1 In 1987, a group of researchers, led by B. MacWhinney and C. E. Snow, developed a set of codes called CHAT (Codes for Human Analyses of Transcripts) and a free tool called CLAN (Computerized Language Analysis) that would help researchers to easily code and analyze samples of spoken language. Also, the usage of a unified file format and coding allows researchers to exchange transcripts, providing tools for cross-linguistic comparisons. In the last two decades, this system has established itself as the most popular tool for the analysis of spoken language corpora. While CHAT and CLAN were originally developed for English, later on they were successfully adopted for other languages. Detailed manuals for using CHAT and CLAN can be found on the CHILDES webpage (MacWhinney, 2010); generally, the CHAT transcription system provides a large toolbox from which researchers can select symbols and conventions needed for their investigation.

2 MORCOMM was primarily designed for tagging and subsequent statistical analysis of the transcripts of Russian texts. MORCOMM automatically runs through the main lines of text written in standard Cyrillic in the CHAT format and creates a special morphological counterpart-line (\%mor) with grammatical codes for every word form.
} 
Each incomplete episode, which includes Goal and Outcome but omits Attempt, scored 3 points. Each incomplete episode, which includes Goal and Attempt but omits Outcome or includes Attempt and Outcome but omits Goal, scored 2 points. Each episode, which includes only Goal but omits Attempt and Outcome, scored 1 point. Since for both The Baby Birds and The Baby Goats sequences 3 episodes (The mother bird, the cat, and the dog; the mother goat, the fox, and the bird) were designed, the episode completeness score can range from $0-12$ points in total.

Internal state terms (IST) include perceptual state terms (e.g., 'see', 'hear'), physiological state terms (e.g., 'thirsty', 'hungry'), consciousness terms (e.g., 'alive', 'awake'), emotion terms (e.g., 'sad', 'happy', 'angry', 'worried', 'disappointed'), mental verbs (e.g., 'want', 'think', 'know', 'forget', 'decide'), and linguistic verbs (e.g., 'say', 'call', 'shout'). Each IST (token) was given 1 point.

\subsubsection{Microstructural characteristics}

General productivity was measured by the total number of word tokens without mazes (TNT) and the total number of communication units (TNCU). A communication unit (CU) is defined as an 'independent clause with its modifiers' (Loban 1976: 9). Rules for segmenting a story into CUs are given in Gagarina et al. $(2012,2015)$ and Hughes et al. (1997: 53-54). In terms of their structure, the majority of the analyzed CUs coincided with a simple syntactic construction, e.g. (1, 2):

(1) Potom mama ptica uletela.

'Then the mother bird flied away.'

(2) A sobaka uvidela i potjanula ego za xvost.

'But the dog saw [him] and grabbed his tail.'

Compound constructions were divided into separate CUs, e.g. (3):

(3) Potom kozlenok prišel k mame s papoj. A vorona za lisoj pognalas’. 'Then the baby goat came back to [his] mother and father. And the crow chased the fox.'

Complex constructions are considered to constitute one CU, e.g. (4):

(4) Kogda [sobaka] ego pot'anula za xvost, on upal i ubežal'. 'When [the dog] grabbed his tail, he fell down and ran away.'

Lexical diversity was measured by the lemma/token ratio (LTR). Although the type/token ratio (TTR) is one of the most commonly used indicators of lexical richness, the LTR is considered more useful when working with smaller speech samples (Granger, Wynne 2000). Attention was given to content words, i.e. nouns, verbs, adjectives, and adjectival adverbs. It should be noted here that the LTR was originally suggested for the English-speaking data as a lexical diversity measure, but in languages with high affix derivation it is closely related to derivational morphology. Namely, in Russian, words such as let'et' 'to fly', ul'et'et' 'to fly away', and pril'et'et' 'to fly back' are treated as three different verb lemmas. Similarly, augmentative and diminutive forms of the same word (e.g., ptica 'bird' - ptička 'bird:DIM', sobaka 'dog' - sobačka 'dog:Dim') are also treated as separate noun lemmas. 
Syntactic complexity was measured by the mean length of CU in words and the CL/CU index. The latter (also called the subordination index) was originally proposed by Hunt (1965) for capturing the complexity of written language, but can also be used for evaluation of oral narratives (Hughes et al. 1997).

\subsubsection{Linguistic dysfluencies}

Linguistic dysfluencies (also called mazes) include hesitations, fillers, repetitions, revisions, and connectors (Loban 1976, Fiestas et al. 2005).

Hesitations can be described as (5) silent (unfilled) or (6) filled pauses (also called fillers) involving the articulation of some sound during the delay (Watanabe, Rose 2012), e.g.:

(5) A (.) koška xot'ela s'est' ptencov.

'And [PAUSE] the cat wanted to eat the baby birds.'

(6) Potom sobaka (.) mmm (.) prognala košku.

'Then the dog [PAUSE-FILLER-PAUSE] chased the cat away.'

Repetitions can be grouped into repeated (7) phrases, (8) words and (9) parts of word.

(7) I skazali (.) i skazali eto (.) svojej mam'e.

'Then [they] told [Pause] then [they] told their mother about this.'

(8) $\underline{I}[$ /] (.) i koza uvid'ela, čto malyš spas'on.

'And [PAUSE] and the goat saw her baby was safe.

(9) Maly-- (.) malyši pt'ency ostalis'odni.

'Baby:InCOMPLETE-PAUSE-baby birds were left alone.'

Revisions can be classified as (10) phonological, (11) lexical, and (12) grammatical modifications of speech.

(10) Prinesla odnogo červ'aka dra (.) dl'a vs'ex ptenčikov.

'[She] brought just one worm for:INCORRECT for all the chicks.'

(11) Potom sobaka prišla i pot'a-- [//] (.) ukusila [košku] za hvost._

'Then the dog came and pulled-[PAUSE-REVISION] grabbed [the cat's] tail.'

(12) Byli (.) bylo mama ptica i tri pt'enca.

'[There] were-PAUSE-REVISION-was a mother bird and three chicks.'

For this study, the absolute number of fillers, repetitions, and revisions within a story was evaluated. Then, individual variables were submitted for statistical analysis.

\subsubsection{Linguistic errors}

Linguistic errors were classified into (13) lexical, (14) grammatical, and (15) stylistic ones, as examplified below:

(13) Potom eje tel'at'ki [= kozl'ata] byli spas'eny.

'Then her calves [= baby goats] were saved.' 
(14) Vyprygnula iz [= iz za] d'er'eva.

'[The fox] jumped out from [ = from behind] a tree.'

(15) I vz'ala [= shvatila/ukusila] lisu za hvost.

'And [the bird] took [= grabbed] the fox's tail.'

During automatic analysis, the measures were estimated for each subject; then, all of these variables were subjected to a one-way ANOVA statistical analysis.

\section{Results}

From the perspective of the conversational and procedural dynamic methodological approach it seems reasonable to make a comparison of narrative production between the groups (TD vs. SLI) in both telling and retelling tasks. As the basic measure, the 1st session of narrative production was established.

Statistical analysis (one-way Anova) indicated that the SLI children's narrative macrostructure was less elaborated as compared with the TD sample. The difference was significant for both telling and retelling (see Table 4, 5).

Table 4. Results of storytelling in the 1st session

\begin{tabular}{|c|c|c|c|c|c|c|c|}
\hline \multirow{2}{*}{ Measure* } & \multicolumn{2}{|c|}{ SLI children } & \multicolumn{2}{|c|}{ TD children } & \multirow{2}{*}{ df } & \multirow{2}{*}{$\mathbf{F}$} & \multirow{2}{*}{ Sig } \\
\hline & Mean & SD & $M$ & SD & & & \\
\hline \multicolumn{8}{|l|}{ Macrostructure } \\
\hline Story structure & 5.00 & 1.00 & 7.20 & 1.09 & 1 & 8.00 & 0.03 \\
\hline Episode completeness & 4.33 & 2.08 & 7.80 & 1.48 & 1 & 7.74 & 0.03 \\
\hline \multicolumn{8}{|l|}{ Microstructure } \\
\hline MLCU & 4.10 & 0.79 & 6.14 & 0.64 & 1 & 16.14 & 0.01 \\
\hline $\mathrm{CL} / \mathrm{CU}$ & 1.00 & 0.00 & 1.13 & 0.08 & 1 & 7.21 & 0.04 \\
\hline TNT-Nouns & 0.35 & 0.05 & 0.28 & 0.03 & 1 & 6.21 & 0.05 \\
\hline
\end{tabular}

* MLCU = mean length of communication units in words; $\mathrm{CL} / \mathrm{CU}=$ subordination index (number of clauses per communication unit); TNT-Nouns = total number of noun tokens.

Table 5. Results of story retelling in the 1st session

\begin{tabular}{|c|c|c|c|c|c|c|c|}
\hline \multirow{2}{*}{ Measure* } & \multicolumn{2}{|c|}{ SLI children } & \multicolumn{2}{|c|}{ TD children } & \multirow{2}{*}{ df } & \multirow{2}{*}{$\mathbf{F}$} & \multirow{2}{*}{ Sig } \\
\hline & $\mathbf{M}$ & SD & $M$ & SD & & & \\
\hline \multicolumn{8}{|l|}{ Macrostructure } \\
\hline Story structure & 5.67 & 0.58 & 8.67 & 1.53 & 1 & 10.12 & 0.03 \\
\hline Episode completeness & 5.00 & 1.00 & 10.0 & 2.00 & 1 & 15.00 & 0.02 \\
\hline IST & 3.33 & 0.58 & 8.00 & 1.73 & 1 & 19.60 & 0.01 \\
\hline \multicolumn{8}{|l|}{ Microstructure } \\
\hline TNT & 37.33 & 8.14 & 81.33 & 23.50 & 1 & 9.39 & 0.04 \\
\hline TNT-Nouns & 10.33 & 2.08 & 22.33 & 5.86 & 1 & 11.17 & 0.03 \\
\hline Noun LTR & 0.75 & 0.12 & 0.46 & 0.09 & 1 & 12.09 & 0.03 \\
\hline TNT-Verbs & 12.00 & 1.73 & 22.67 & 3.51 & 1 & 22.26 & 0.01 \\
\hline TNDW-Verbs & 10.33 & 1.15 & 18.00 & 3.46 & 1 & 13.22 & 0.02 \\
\hline TNT-Adjectives & 0.00 & 0.00 & 0.07 & 0.04 & 1 & 7.74 & 0.05 \\
\hline
\end{tabular}

* IST = number of internal state terms (tokens); TNT = total number of word tokens without mazes; TNT-Nouns = total number of noun tokens; Noun LTR = noun lemma/token ratio; TNT-Verbs = total number of verb tokens; TNDW-Verbs $=$ total number of different verbs; TNT-Adjectives $=$ total number of adjective tokens. 
The general linear model of dispersion statistical analysis revealed a significant influence of the task mode (telling vs. retelling) on the story structure in the SLI group (see Table 6): the text of the retold story had a much more elaborated structure than the text of the generated (told) story.

The point of this study was to evaluate not only static but also dynamic measures, i.e. the impact of the session on narrative micro- and macrostructure in both TD and SLI children (see Table 6).

Table 6. The impact of independent variables on the macrostructural measures

\begin{tabular}{|l|c|c|c|c|c|c|c|}
\hline \multirow{2}{*}{ Independent variable } & \multicolumn{3}{|c|}{ SLI children (N = 12) } & \multicolumn{3}{c|}{ TD children (N = 12) } \\
\cline { 2 - 8 } & $\mathbf{F}$ & Sig & $\mathbf{\eta}^{\mathbf{2}}$ & $\mathbf{F}$ & Sig & $\mathbf{\eta}^{\mathbf{2}}$ \\
\hline Story structure & 10.80 & 0.03 & 0.73 & 9.52 & 0.01 & 0.49 \\
\hline Session & 8.53 & 0.04 & 0.68 & - & - & - \\
\hline Mode & & & & & \\
\hline Episode completeness & 10.04 & 0.03 & 0.72 & 5.58 & 0.04 & 0.36 \\
\hline Session &
\end{tabular}

In both the SLI and the TD children, the session factor (1st vs. 2nd session) was very influential for the story structure, respectively $\mathrm{F}=10.8 ; \mathrm{P} \leq 0.003$; and $\mathrm{F}=5.8$; $\mathrm{P} \leq 0.043$ (see Table 6). Generally, narratives produced in the 2nd session were more elaborated than those produced in the 1st one. As expected, narrative microstructure in the SLI children was less developed, but this limitation manifested itself only in a few measures (see Table 7). It should be noted that these limitations were different in telling and retelling mode. Syntactic weakness (MLCU and CL/CU) was revealed only in telling mode (see Table 4). Verbal productivity (total number of word tokens without mazes), noun lemma/token ratio, and the total number of verb and adjective tokens were low in only the retelling mode. It is interesting to note that SLI children were relatively overproductive in a number of noun tokens in the telling condition. But when retelling, they did not differ from their TD peers.

Table 7. The impact of independent variables on the microstructural measures

\begin{tabular}{|c|c|c|c|c|c|c|}
\hline \multirow{2}{*}{ Independent variable } & \multicolumn{3}{|c|}{ SLI children ( $N=12)$} & \multicolumn{3}{|c|}{ TD children ( $N=12)$} \\
\hline & $\mathbf{F}$ & Sig & $\eta^{2}$ & $\mathbf{F}$ & Sig & $\eta^{2}$ \\
\hline \multicolumn{7}{|c|}{ Total number of Communication Units } \\
\hline Session & - & - & - & 19.27 & 0.000 & 0.71 \\
\hline Mode & - & - & - & 5.40 & 0.05 & 0.40 \\
\hline Story $\mathrm{x}$ session & - & - & - & 64.07 & 0.000 & 0.91 \\
\hline Story $\mathrm{x}$ mode & - & - & - & 81.67 & 0.000 & 0.91 \\
\hline Session $\mathrm{x}$ mode & 14.29 & 0.02 & 0.78 & 81.67 & 0.000 & 0.91 \\
\hline \multicolumn{7}{|l|}{ Total number of words } \\
\hline Story $\mathrm{x}$ session & - & - & - & 11.09 & 0.01 & 0.58 \\
\hline Story $x$ mode & - & - & - & 6.22 & 0.04 & 0.44 \\
\hline Session $\mathrm{x}$ mode & - & - & - & 13.67 & 0.01 & 0.63 \\
\hline
\end{tabular}




\begin{tabular}{|l|r|r|r|r|r|r|}
\hline Noun lemma/token ratio & 0.79 & 0.04 & 0.69 & - & - & - \\
\hline Story & 46.91 & 0.00 & 0.92 & - & - & - \\
\hline Mode & 14.28 & 0.02 & 0.78 & 61.60 & 0.000 & 0.88 \\
\hline Session x mode & 7.41 & 0.05 & 0.65 & - & - & - \\
\hline Percentage of noun tokens & 9.26 & 0.04 & 0.70 & - & - & - \\
\hline Story & 21.56 & 0.01 & 0.84 & - & - & - \\
\hline Session & - & - & - & 11.43 & 0.01 & 0.59 \\
\hline Mode & 11.31 & 0.028 & 0.74 & - & - & - \\
\hline Story x session & & & & & - \\
\hline Story x mode & 27.00 & 0.01 & 0.87 & - & - & - \\
\hline Total number of grammatical errors & &
\end{tabular}

The SLI children made more linguistic (grammatical, lexical, and stylistic) errors than their TD peers. Linguistic dysfluencies, by contrast, were more frequent in the TD children, but the difference in the number of both linguistic errors and dysfluencies was neither significant nor influenced by the dynamic measures.

\section{Discussion and conclusions}

The conversational and psycholinguistic approach to narrative production incorporates speech processing, communicative speech act construction, and cognitive execution. As a complex process, narrative production is influenced by many paralinguistic factors, and this may result in some particular changes in the narrative text measures. The current study provided significant evidence of this. First, the main narrative macrostructure measures in our participants were significantly dependent on the session; i.e. the structure of stories told in the 2nd session was much more elaborated as compared to stories told in the 1st session. Although this influence was different for telling and retelling, it should be noted that the session variable was more influential than the story mode: the measures of both story structure and episode completeness were different in the 1st and the 2nd sessions, while the story mode influenced only episode completeness.

Another interesting finding was that the SLI and the TD children demonstrated different dynamic variation from the perspective of both the session and mode variables as well as of their interaction. SLI children in story production were most susceptible in macrostructure to the dynamic influence of both session and mode. This corresponds with our previous findings that atypically developing children have cognitive resource limitations resulting in dynamic variations in narrative macrostructure.

The current narrative microstructure analysis in SLI children revealed selective limitations in some linguistic measures. These are the index of syntactic complexity (CL/CU) and adjective productivity. On the other hand, SLI children used nouns in their narratives much more frequently than their TD peers. Presumably, their limitation in using referential pronouns could be one of the preliminary 
explanations for this fact. This suggestion is based on the results of a qualitative distributional analysis of the same SLI children's conversational vocabulary. The frequency of demonstrative and personal pronouns was significantly lower in the corpus of SLI than in the corpus of the TD children (Kornev, Balčiūnienè 2016).

It should be emphasized that all the measures that distinguish SLI from TD children were strongly influenced by the session and mode variables. These measures, being weak linguistic devices in the SLI children, were dependent on the interaction of the session and the mode (and some of them were additionally dependent on the story variable). It seems reasonable to treat this uneven functional effectiveness as a trade-off effect of competing for cognitive resources and cognitive, semantic, syntactic, and lexical processes. The more cognitive loading of some language procedure is required, the less cognitive resource is left for the remaining components of narrative production. To verify this prediction, a correlational analysis of the micro- and macrostructural measures that significantly distinguish SLI and TD narratives was carried out. In the SLI children, the number of nouns per word within a story was negatively correlated with the story structure $(\mathrm{r}=-0.41 ; \mathrm{P}<0.05)$, episode completeness measures ( $\mathrm{r}=-0.41 ; \mathrm{P}<0.05)$; and CL/CU. Hence, the CL/CU ratio was closely related to complex syntactic structures and negatively affected the production of modifiers (these were substituted by nouns). By contrast, the TD children's narratives did not highlight any such correlations. Similar evidence has been found by Colozzo et al. (2011); they have concluded that narrative macrostructure and microstructure were in reciprocal relations in the clinical population, i.e. the SLI children produced either stories with poor macrostructure that were grammatically quite accurate or stories with elaborated macrostructure that were less grammatical. The SLI sample slowed down episode completeness in The Baby Goats story, while the controls demonstrated - to the contrary - lower results in The Baby Birds story. Also, the story complexity interacted with the mode factor. It should be noted here that retelling, as compared to telling, gives a child additional support in developing a coherent narrative structure. On the other hand, story text presented to a child for retelling requires conforming to the model. In our previous studies (Kornev, Balčiūnienė 2014, 2015), dyslexic children had demonstrated better story structure in telling The Baby Birds in the 2nd session after the retelling of The Baby Goats story in the 1st session. In the current study, some measures (story structure $\mathrm{F}=4.06, \mathrm{P}=0.072$ and internal state terms $(\mathrm{F}=4.06, \mathrm{P}=0.072)$ in the SLI children were better in the retelling mode, while the TD children did not demonstrate such differences. Most likely, this data demonstrates that the story model gives the SLI children some additional support for story production that results in rising story structure scores.

Session order was also a powerful factor for both the SLI and the TD children and it closely interacted with the mode factor. Story structure and structural complexity usually had the best scores in the 2nd session (see table 5). The plausible explanation of this difference might be related to the new experience obtained by the participant in the 1st session. It incorporates narrative production activity (in telling or retelling) and answering the comprehension questions (CQ). This experience resulted in a twofold effect: a priming effect (narrative (re-)production) and prompting in story grammar construction (when answering to CQ). 
These findings correspond with the results of our previous studies (Kornev, Balčiūnienè 2014, 2015) and suggest a two-way explanation. In the case of telling after retelling, the priming effect might have a strong impact; i.e. a text presented for retelling in the 1st session activates the relevant cerebral network, and thus leads to better results of storytelling in the 2nd session. Additionally, answering CQ might make it easier to construct story grammar in the 2nd session. In the inverse case, the 2nd session preference could be the result of a modelling effect related to answering CQ. It should be taken into account that comprehension questions were presented after either telling or retelling. The questions presumably helped children to focus on significant points of the story plot and thus led to a more coherent narrative in the next session. The impact of session order was dependent on the story mode and complexity factors; namely, the SLI children demonstrated a high percentage of noun tokens in the telling mode. Syntactic complexity (CL/CU ratio) was the weak point of SLI children in only telling but not in retelling mode. The cause of this difference still remains unclear and needs more complex analysis in a larger test group.

The data obtained in the current study gave us new evidence of advantages of dynamic approach to narrative analysis. From the perspective of this approach, various different factors significantly influence qualitative and quantitative measures of narrative text; hence, both linguistic and procedural limitations prevent the SLI children from producing well-elaborated and grammatical text. It should particularly be taken into account in the remedial treatment practice that story (re-)telling combines cognitive and linguistic processes, thus (S)LI children might evidence procedural limitations that look like simply a language deficit.

Despite some limitations (e.g. the relatively small number of subjects) of the study, it may be generally concluded that the dynamic approach to narrative analysis is quite an informative and practically oriented tool for assessing SLI children. It gives a valuable opportunity to test a wide scope of structural and procedural linguistic capacities in SLI children and its outcomes allow for an individualized (and thus - more effective) speech/language treatment course.

Remedial treatment of SLI children usually incorporates developing discourse production skills as a target, but these skills are not uniform; rather, they are based on multiple cognitive and linguistic subskills. Thus a speech/language pathologist should develop the weak functions while reinforcing the strong ones. In order to disentangle a variety of these skills and to distinguish the weak mechanisms from the intact ones, speech/language pathologists should use reliable tools for clinical assessment.

$\begin{array}{ll}\text { Abbreviations } \\ \text { CLAN } & \text { Computerized Language Analysis } \\ \text { CHAT } & \text { Codes for Human Analyses of Transcripts } \\ \text { CL/CU } & \text { clause/communication unit ratio } \\ \text { CQ } & \text { comprehension question } \\ \text { CU } & \text { communication unit } \\ \text { DIM } & \text { diminutive } \\ \text { ENNI } & \text { Edmonton Narrative Norms Instrument } \\ \text { IQ } & \text { intellectual quotient }\end{array}$




$\begin{array}{ll}\text { LTR } & \text { lemma/token ratio } \\ \text { MAIN } & \text { Multilingual Assessment Instrument for Narratives } \\ \text { MORCOMM } & \text { The program of morphological coding } \\ \text { RAIN } & \text { Russian Assessment Instrument for Narratives } \\ \text { Sig } & \text { significance } \\ \text { SD } & \text { standard deviation } \\ \text { SLI } & \text { specific language impairment } \\ \text { TD } & \text { typically-developing } \\ \text { TNCU } & \text { total number of communication units } \\ \text { TNDW } & \text { total number of different words } \\ \text { TNL } & \text { total number of lemmas } \\ \text { TNT } & \text { total number of tokens } \\ \text { TTR } & \text { type/token ratio }\end{array}$

\section{References}

Applebee, Arthur N. 1978. The Child's Concept of a Story: Ages 2 to 17. Chicago, IL: University of Chicago Press.

Bliss, Lynn S.; McCabe, Allyssa; Miranda, Elizabeth A. 1998. Narrative assessment profile: Discourse analysis for school-age children. - Journal of Communication Disorders, 31 (4), 347-363. http://dx.doi.org/10.1016/So021-9924(98)00009-4

Bokus, Barbara; Wales-Shugar, Grace 1998. Social structures of children's narrational activity. - Psychology of Language and Communication, 2 (1), 75-81.

Caramelli, Nicoletta; Borghi, Anna M.; Tison, Carla 1998. The textual pre-conditions for action narration in children's story construction. - Psychology of Language and Communication, 2 (2), 47-56.

Colozzo, Paola; Gillam, Ronald B.; Wood, Megan; Schnell, Rebecca D.; Johnston, Judith R. 2011. Content and form in the narratives of children with specific language impairment. - Journal of Speech, Language, and Hearing Research, 54 (6), 1609-1627. http://dx.doi.org/10.1044/1092-4388(2011/10-0247)

Duinmeijer, Iris; de Jong, Jan; Scheper, Annette 2012. Narrative abilities, memory and attention in children with a specific language impairment. - International Journal of Language \& Communication Disorders, 47 (5), 542-555. http://dx.doi. org/10.1111/j.1460-6984.2012.00164.X

Fey, Marc E.; Catts, Hugh W.; Proctor-Williams, Kerry; Tomblin, Bruce J.; Zhang, Xuyang 2004. Oral and written story composition skills of children with language impairment. - Journal of Speech, Language, and Hearing Research, 47 (December), 1301-1318. http://dx.doi.org/10.1044/1092-4388(2004/098)

Fiestas, Christine E.; Peña, Elisabeth D. 2004. Narrative discourse in bilingual children: Language and task effect. - Language, Speech, and Hearing Services in Schools, 35 (April), 155-168. http://dx.doi.org/10.1044/0161-1461(2004/016)

Fiestas, Christine E.; Bedore, Lisa M.; Peña, Elizabeth D.; Nagy, Vanessa J. 2005. Use of mazes in the narrative language samples of bilingual and monolingual 4- to 7-year old children. - James Cohen, Kara T. McAlister, Kellie Rolstad, Jeff MacSwan (Eds.), Proceedings of the 4th International Symposium on Bilingualism. Somerville, MA: Cascadilla Press, 730-740.

Gagarina, Natalia; Voeikova, Maria; Gruzincev, Sergej 2003. New version of morphologically coding for speech production of Russian children (in the framework of CHILDES). - Peter Kosta, Joanna Błaszczak, Jens Frasek, Ljudmila Geist, Marzena Żygis (Eds.), Investigations Into Formal Slavic Linguistics. Contributions of the Fourth European Conference on Formal Description of Slavic Languages: FDSL IV, November 28-30, 2001. Frankfurt am Main: Peter Lang, 243-258. 
Gagarina, Natalia; Klop, Daleen; Kunnari, Sari; Tantele, Koula; Välimaa, Taina; Balčiūnienè, Ingrida; Bohnacker, Ute; Walters, Joel 2012. MAIN: Multilingual Assessment Instrument for Narratives. ZAS Papers in Linguistics 56. Berlin: ZAS.

Gagarina, Natalia; Klop, Daleen; Kunnari, Sari; Tantele, Koula; Välimaa, Taina; Balčiūnienė, Ingrida; Bohnacker, Ute; Walters, Joel 2015. Assessment of narrative abilities in bilingual children. - Sh. Armon-Lotem, J. de Jong, N. Meir (Eds.), Assessing Multilingual Children: Disentangling Bilingualism from Language Impairment. Multilingual Matters, 243-276.

Gillam, Ronald B.; Pearson, Nils A. 2004. Test of Narrative Language. Austin, TX: Pro-Ed.

Granger, Sylviane; Wynne, Martin 2000. Optimising measures of lexical variation in EFL learner corpora. - John Kirk (Ed.), Corpora Galore. Amsterdam-Atlanta: Rodopi, 249-257.

Hickmann, Maya 2003. Children's Discourse: Person, Space and Time Across Languages. Cambridge: Cambridge University Press.

Hickmann, Maya; Hendriks, Henriette 1999. Cohesion and anaphora in children's narratives: A comparison of English, French, German, and Mandarin Chinese. - Journal of Child Language, 26 (2), 419-452. http://dx.doi.org/10.1017/S0305000999003785

Hughes, Diana; McGillivray, LaRae; Schmidek, Mark 1997. Guide to Narrative Language. Procedures for Assessment. Austin: PRO-ED, Inc.

Hunt, Kellogg 1965. Grammatical Structures Written at Three Grade Levels. National Council of Teachers of English. Urnana, Ill.

Justice, Laura M.; Bowles, Ryan P.; Kaderavek, Joan N.; Ukrainetz, Teresa A.; Eisenberg, Sarita I.; Gillam, Ronald B. 2006. The index of narrative microstructure (INMIS): A clinical tool for analyzing school-age children's narrative performances. - American Journal of Speech-Language Pathology, 15 (May), 177-191. http://dx.doi. org/10.1044/1058-0360(2006/017)

Kornev, Aleksandr N.; Balčiūnienė, Ingrida 2014. Story (re-)telling and reading in children with dyslexia: Language or cognitive resource deficit? - Book of Abstracts: LSCD2014. London: UCL, 23-26.

Kornev, Aleksandr N.; Balčiūnienė, Ingrida 2015. Narrative production weakness in Russian dyslexics: Linguistic or procedural limitations? - Estonian Papers in Applied Linguistics, 11, 141-157. http://dx.doi.org/10.5128/erya11.09

Kornev, Aleksandr N.; Balčiūnienè, Ingrida 2016. Referencial'nost' v narrativax detej s pervičnym nedorazvitijem reči. [Referential cohesion in narratives of SLI children.] Materialy meždunarodnoj konferenciji “Ontolingvistika-2016" [Proceedings of international conference "Ontolingvistika-2016".] In press.

Kramer, Kenda; Mallett, Patricia; Schneider, Phyllis; Hayward, Denyse 2009. Dynamic assessment of narratives with grade 3 . Children in a first nations community. - Revue canadienne d'orthophonie et d'audiologie, 33 (3), 119-128.

Larson, Vicki Lord; McKinley, Nancy L. 1995. Language Disorders in Older Students: Preadolescents and Adolescents. Eau Claire, WI: Thinking Publications.

Leonard, Laurence B. 2014. Children with Specific Language Impairment. Second edition. Cambridge, MA: MIT Press.

Loban, Walter 1976. Language Development: Kindergarten Through Grade Twelve. National Council of Teachers of English. Urnana, Ill.

MacWhinney, Brian 2010. The CHILDES Project: Tools for Analyzing Talk. Electronic Edition. http://childes.psy.cmu.edu/manuals/CLAN.pdf (23.9.2011).

Mayer, Mercer 1967. A Boy, a Dog and a Frog. New York: Penguin.

Mayer, Mercer 1969. Frog, Where Are You? New York: Penguin.

Mayer, Mercer 1974. Frog Goes to Dinner. New York: Penguin.

McCabe, Allyssa; Bliss, Lynn S. 2003. Patterns of Narrative Discourse: A Multicultural, Life Span Approach. Boston, MA: Allyn and Bacon. 
Miller, Lynda; Gillam, Ronald B.; Peña, Elisabeth D. 2001. Dynamic assessment and intervention: Improving children's narrative abilities. Austin, TX: PRO-ED.

Nelson, Katherine 1996. Language in Cognitive Development. Cambridge: Cambridge University Press. http://dx.doi.org/10.1017/CBO9781139174619

Peña, Elisabeth D.; Gillam, Ronald B.; Malek, Melynn; Ruiz-Felter, Roxanna; Resendiz, Maria; Fiestas, Christine; Sabel, Tracy 2006. Dynamic assessment of school-age children's narrative ability: An experimental investigation of classification accuracy. - Journal of Speech, Language, and Hearing Research, 49 (October), 1037-1057. http://dx.doi. org/10.1044/1092-4388(2006/074)

Reilly, Judy; Losh, Molly; Bellugi, Ursula; Wulfecket, Beverly 2004. "Frog, Where Are You?" Narratives in children with specific language impairment, early focal brain injury, and Williams syndrome. - Brain and Language, 88 (2), 229-247. http://dx.doi. org/10.1016/So093-934X(03)00101-9

Renfrew, Catherine E. 1969. The Bus Story: A Test of Continuous Speech. North Place, Old Headington: Oxford.

Reuterskiöld, Christina; Hansson, Kristina; Sahlén, Birgitta 2011. Narrative skills in Swedish children with language impairment. - Journal of Communication Disorders, 44 (6), 733-744. http://dx.doi.org/10.1016/j.jcomdis.2011.04.010

Schneider, Phyllis 1996. Effects of pictures versus orally presented stories on story retellings by children with language impairment. - American Journal of Speech-Language Pathology, 5 (February), 86-96. http://dx.doi.org/10.1044/1058-0360.0501.86

Schneider, Phyllis; Dubé, Rita Vis 2005. Story presentation effects on children's retell content. - American Journal of Speech-Language Pathology, 14 (February), 52-6o. http:// dx.doi.org/10.1044/1058-0360(2005/007)

Schneider, Phyllis; Dubé, Rita Vis; Hayward, Denyse V. 2005. The Edmonton Narrative Norms Instrument (ENNI). https://rehabilitation.ualberta.ca/departments/ communication-sciences-and-disorders/resources-for-clinicians-and-researchers/ edmonton-narrative-norms-instrument (2.3.2016).

Soodla, Piret; Kikas, Eve; Pajusalu, Renate; Adamka, Aive; Parm, Sirli 2010. Vahendamata ja vahendatud narratiiv laste kõnearengu hindamisel. [Self-generated and retold narratives as a tool of language assessment.] - Eesti Rakenduslingvistika Ühingu aastaraamat, 6, 277-296. http://dx.doi.org/10.5128/ERYa6.17

Stein, Nancy L.; Glenn, Christine G. 1979. An analysis of story comprehension in elementary school children. - R. O. Freedle (Ed.), New Directions in Discourse Processing (Vol. 2). Norwood, NJ: Ablex, 53-120.

Stein, Nancy L.; Glenn, Christine G. 1982. Children's concept of time: The development of story schema. - W. J. Friedman (Ed.), The Developmental Psychology of Time. New York: Academic Press, 255-282.

Squires, Katie E.; Lugo-Neris, Mirza J.; Peña, Elisabeth D.; Bedore, Lisa M.; Bohman, Thomas M.; Gillam, Ronald B. 2014. Story retelling by bilingual children with language impairments and typically developing controls. - International Journal of Language \& Communication Disorders, 49 (1), 60-74. http://dx.doi.org/10.1111/1460-6984.12044

van der Lely, Heather K. J. 1997. Narrative discourse in Grammatical specific language impaired children: A moduar language deficit? - Journal of Child Language, 24 (1), 221-256. http://dx.doi.org/10.1017/S0305000996002966

van Kleeck, Anne; Lange, Alissa; Schwarz, Amy L. 2011. The effects of race and maternal education level on children's retells of the Renfrew Bus Story - North American Edition. - Journal of Speech, Language, and Hearing Research, 54 (December), 1546-1561. http://dx.doi.org/10.1044/1092-4.388(2011/10-0079)

Vandewalle, Ellen; Boets, Bart; Boons, Tinne; Ghesquie, Pol; Zink, Inge 2012. Oral language and narrative skills in children with specific language impairment with and without 
literacy delay: A three-year longitudinal study. - Research in Developmental Disabilities, 33 (6), 1857-1870. http://dx.doi.org/10.1016/j.ridd.2012.05.004

Veneziano, Edy; Hudelot, Christian 2009. Explaining events in narratives: The impact of scaffolding in 4 to 12 year old children. - Psychology of Language and Communication, 13 (1), 3-20. http://dx.doi.org/10.2478/v10057-009-0001-X

Watanabe, Michiko; Rose, Ralph L. 2012. Pausology and hesitation phenomena in second language acquisition. - Peter Robinson (Ed.), The Routledge Encyclopedia of Second Language Acquisition. New York-London: Routledge, 480-483.

Wetherell, Danielle; Botting, Nicola; Conti-Ramsden, Gina 2007. Narrative in adolescent specific language impairment (SLI): A comparison with peers across two different narrative genres. - International Journal of Language \& Communication Disorders, 42 (5), 583-605. http://dx.doi.org/10.1080/13682820601056228

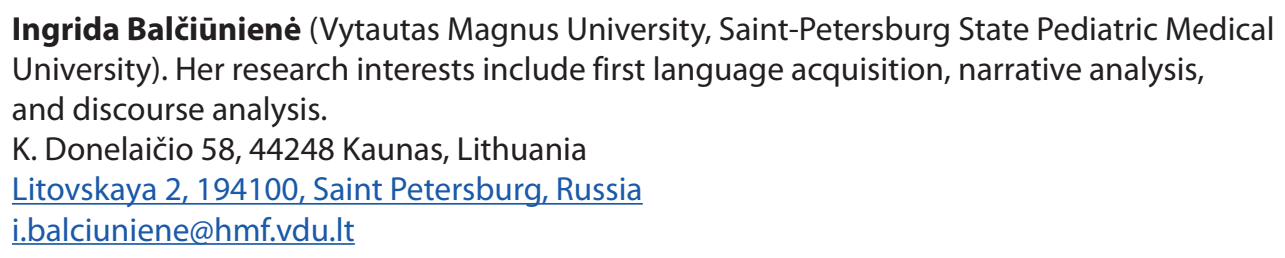

Aleksandr N. Kornev (Saint-Petersburg State Pediatric Medical University). His research interests include child clinical psychology, speech/language pathology, and dyslexia. Litovskaya 2, 194100, Saint Petersburg, Russia

k1949@yandex.ru 


\section{UUED KEELELISED TEGEVUSED: SPETSIIFILISE KÕNEARENGU PUUDEGA KOOLIEELIKUTE NARRATIVIKEEL}

Ingrida Balčiūnienè ${ }^{1,2}$, Aleksandr N. Kornev²

Vytautas Magnuse Ülikool ${ }^{1}$, Peterburi Riiklik Pediaatriameditsiini Ülikool ${ }^{2}$

Artikkel käsitleb narratiivi mikro- ja makrostruktuursete tunnuste dünaamikat venekeelsetel spetsiifilise kõnearengu puudega koolieelikutel. Uurimismaterjal on kogutud katsega, mis sisaldas loo jutustamist ja seejärel ümberjutustamist sõnadeta pildiseeriate abil. Katserühm koosnes 12 venekeelsest spetsiifilise kõnearengu puudega 6-aastasest koolieelikust ja kontrollrühm 12 arenguhäireta eakaaslasest.

Esmalt hinnati ja võrreldi katseisikute ja kontrollgrupi narratiivide üksikuid näitajaid, nagu jutustuse ülesehitus, episoodide terviklikkus, seisundisõnad (narratiivi makrostruktuursed tunnused), üldine produktiivsus, leksikaalne mitmekesisus, süntaktiline keerukus (narratiivi mikrostruktuursed tunnused), protsentuaalselt ka lingvistilise soravuse segajaid, nagu takerdused, täitesõnad, kordused, parandused, ühendused, ning veakategooriaid (leksikaalsed, grasmmatilised, stilistilised vead).

Teiseks mõõdeti selliste faktorite nagu sessiooni (1. vs. 2.), loo keerukuse ja laadi (jutustus vs. ümberjutustus) mõju narratiivi mikro- ja makrostruktuursete näitajate dünaamilisele varieerumisele. Uurimustulemused valgustasid katsejuhtumite peamisi dünaamilisi erinevusi narratiivi ülesehituse, struktuurse keerukuse, grammatilisuse ja sõnavara vaatepunktist.

Võtmesõnad: narratiivianalüüs, diskursusanalüüs, dünaamiline varieerumine, kõnearengu puue, keeleoskuse hindamine, vene keel 